\title{
EXERCISE OF THE PRESIDENTIAL POWERS IN THE SLOVAK REPUBLIC IN A COMPARATIVE PERSPECTIVE (1999 - 2019)
}

\author{
Peter Horváth ${ }^{1}$, Peter Juza ${ }^{2}$, León Richvalský3, Marek Šafár ${ }^{4}$
}

\begin{abstract}
This article focuses at powers of the Presidents of the Slovak Republic during the period from 1999 to 2019. Therefore, the aim is to compare how selected constitutional presidential powers were exercised after the fundamental constitutional changes in 1999. The most significant change was by introducing direct presidential elections, and adjusting the President's constitutional status. The ways how the individual Presidents holding their office within this period, exercised their powers towards the Parliament, government, and the judiciary do form the basic research questions here. Hence, whether a personal background of individual Presidents and political reality of seats distribution in the Parliament predetermined their exercise of these powers, or if there were some other rules present when they exercised their office. The findings presented in this research reflect 20 years of continuous exercise of Presidential office in the conditions of the Slovak Republic. This ultimately leads to the conclusion that the function itself, as well as its constitutional definition, has affected the exercise of Presidential powers more ultimately than the personal background of these directly elected Presidents at the beginning of their terms of office. The very first President, Mr. Michal Kováč, got into a major conflict with then Prime Minister, Vladimír Mečiar, even during the first year after taking the office. This conflict lasted nearly for fiveyears and altogether with the inability of the MPs to elect his successor led to the necessity of amending the Constitution. Presidents Rudolf Schuster, Ivan Gašparovič and Andrej Kiska gradually took their office, but only the second mentioned had managed to defend his position in an electoral competition. At present, the office of President is held by Zuzana Čaputová, who has been in the office since June 2019 - as the very first woman in this position in history of Slovakia.
\end{abstract}

KEY WORDS: Presidential powers, Presidential elections, Slovak Republic, Constitutional system, Legislative process, Pardon, Amnesty, State decorations.

\footnotetext{
${ }^{1}$ Faculty of Social Sciences, University of Saints Cyril and Methodius in Trnava, Bučianska 4/A, 91701 Trnava, Slovak Republic. E-mail: peter.horvath@ucm.sk. ORCID: 0000-0001-9117-7247. ${ }^{2}$ Faculty of Arts, Pavol Jozef Šafárik University in Košice, Šrobárova 2, 04059 Košice, Slovak Republic.E-mail: peter.juza@upjs.sk.

${ }^{3}$ Faculty of Social Sciences, University of Saints Cyril and Methodius in Trnava, Bučianska 4/A, 91701 Trnava, Slovak Republic. E-mail: leon.richvalsky@ucm.sk, ORCID: 0000-0003-3592-5495. ${ }^{4}$ Faculty of Social Sciences, University of Saints Cyril and Methodius in Trnava, Bučianska 4/A, 91701 Trnava, Slovak Republic. E-mail: marek.safar@ucm.sk. ORCID: 0000-0002-4075-9914.
} 


\section{INTRODUCTION}

The topic of this study turns to the matters of exercising the powers of the President of the Slovak Republic (hereinafter referred to as "the President", "Slovakia") after a direct electoral procedure was adopted in a Presidential election. The main goal of this paper is, therefore, to analyse the real exercise of selected constitutional powers of the Presidents (hereinafter referred to as "presidential powers") during the last 20 years, i.e. after this office has been held by directly - elected political elites of Slovakia. The analysis focuses, especially, on the powers implementation of which is guaranteed by the Constitution to be exclusive presidential powers. Basically, our does not include a monitoring of the competences, where the Presidents are only the mere implementers of decisions made by other constitutional representatives - the appointment of a member of the government or the rector of a public university, for example. The primary research question is, therefore, whether an exercise of the presidential powers is influenced by some various factors, such as the personality of an individual representative (the personality of the President) in this office, or the exercise itself is more likely the result of his constitutional powers, hence the personality component is more secluded. In addition, other partial research questions are followed here. First is whether the exercise of the office of the President is influenced by a matter of consistency between the President and the Prime Minister (a leader of the government) concerning their political orientation. The second question is to have a further look at the question of whether the constitutional exercise of the Presidential powers is also affected by the possibility of two subsequent terms of office, within which the competences are exercised (however, valid only in the case of Ivan Gašparovič). Therefore, the main research method is a comparison based on the data obtained especially from the official websites of the individual Presidents, on the official data released by the National Council of the Slovak Republic, and from the scholarly literature in this matter. In addition, in order to answer the given research questions, or to formulate the assumptions of further development in this area, the methods of analysis and synthesis were applied for processing the data obtained as well.

In Central Europe, the matters concerned a President's position turned to perception that was more intensive after the political changes in 1989. Strong personalities of Presidents Václav Havel and Lech Walesa, as a matter of course, had brought the presidency-related issues to a spotlight (Kubát, 2013). Later, after the establishment of an independent Slovak Republic in 
1993 and with Michal Kováč holding this office, political studies began to appear in Slovak Republic as well. Amendment of the Constitution in 1999 did change more than a mere electoral procedure (i.e. a change to direct vote by people not by the MPs), but this amendment also modified individual presidential competences fundamentally. For more than 20 years, in Slovakia the head of state receives direct mandate from the citizens in presidential elections. At present, the fourth Slovak President with such apparently strong political mandate resides in the Presidential Palace. So far, there was only one President, Ivan Gašparovič, who sustained his mandate and held this most significant position in the country's political system for two consecutive terms. At the very beginning of independent Slovak history (i.e. from 1993), the position of President was held by the candidates elected to this office by the Parliament, i.e. by an indirect procedure. Thus, Michal Kováč has created the basic image of the presidency in Slovak Republic. His presidential term is significant to mention as the end of his term turned the country to a political turbulence. This was predominantly caused by the electoral procedure itself. The two-round electoral procedure required a presidential candidate to obtain a necessary constitutional majority of the MPs, and in any round of elections. After the end of Michal Kováčs term, no candidate managed to obtain such a majority - for more than a year (Orosz, Šimuničová, 1998; Čič, 1997). The change of the government in 1998 also resulted in the consecutive adoption of an amendment to the Constitution of the Slovak Republic, which changed the electoral procedure of the President from an indirect (i.e. a candidate elected by members of the National Council of the Slovak Republic) to a direct election (ie. by the citizens in public elections) (Kopeček, 2003). However, the scope of competences and powers of the head of state also changed, but not significantly (Čič, 2012; Tóthova, 2015; Drgonec, 2015). The change of the Presidential powers was the result of several events and circumstances that had gradually developed. Thus, the competences were adjusted closer to the parliamentary form of government (also within the further significant amendment to the fundamental law in 2001). The country witnessed strengthening of the formal character of Presidential mandate (since this Office was no longer derived from the political will of members of the parliament, but directly from the will of citizens), but on the other hand, the powers were weakened in some other areas (Belko, 2003). The need for a single candidate competing within simple electoral rule, which is expected to receive ultimately a majority of votes, has led the legislators to implement a majority voting system with an absolute majority. Just as an example of good practices, a similar 
electoral system was introduced later in 2001 in the election of a chairman of the regional government. Comparing these two electoral procedures, the only major difference is in the first round of presidential election, where a candidate needs to obtain an absolute majority of votes from all eligible voters (Bardovič, 2017).

When comparing the first President Michal Kováč to the subsequent Presidents after 1999, the most significant example of weakening of the Presidential competences is the omission of any alternative decision-making possibilities of the President, in the matters of appointment or dismissal of members of the government. Until the constitutional change in 1999, the head of state enjoyed very strong competence in relation to another executive body - the government of the Slovak Republic. The President, elected by the Parliament, had an absolute right of veto in relation to appointment of individual members of the government, as well as to proposals of their dismissal. According to the finding of the Constitutional Court of the Slovak Republic, the President was then obliged to deal with the proposal of the Prime Minister and decide for the appointment or dismissal, but the final decision and the right to refuse a PM proposed was under the President's powers (Čič, 1997). The President used this power in the case of Ivan Lexa for example, when he rejected the proposal of Prime Minister Vladimír Mečiar to appoint Ivan Lexa to the position of a member of the government. Nevertheless, Ivan Lexa politically managed the Ministry of Privatization in the end (he took control as the government-appointed Secretary of State, because of the vacant post of the minister) (Horváth, Juhás, 2011). Another practical example of such use of Presidential power was the rejection of the proposal to dismiss minister Milan Kňažko in early 1993. This situation was resolved in the end, as the minister Milan Kňažko resigned from his office (Kopeček, 2003). The Slovak Republic has not encountered such Presidential powers in practice before, and it has turned out to be a possible political problem in certain ways. When a constitutional majority of Parliament elected the President, it was mainly an expression of political support, and such President could potentially prevent obvious change of government based on the results of following parliamentary elections (parliamentary term is 4 years, Presidential term 5 years). Thus, after the post-electoral change of parliament, the exercise of the will of the citizens might have been suppressed by the President, due to the change of elected representatives. Subsequent constitutional adjustments of the Presidential position revised his/her competencies towards the traditional understanding of the positon of head of state within the parliamentary form of government, but at the 
same time, the possibility of his/her early resignation was also adjusted. In the original constitutional regulation, the Parliament was able to dismiss the President by three-fifths-majority of votes - exactly as in the case of his/her election. Thus, the President was under the direct control of the legislature, because the question of a proper exercise of the entire mandate also depended on whether the legislators had confidence towards the President (Čič, 1997; Orosz, Šimuničová, 1998; Kopeček, 2003). Hence, the new regulation reflects again the will of the ones who appointed him/her to the Office - the citizens of the Slovak Republic. In this case precisely, the legislature is regulated in such a way that the proposer (the National Council of the Slovak Republic) has a sanction in the form of early termination of parliamentary mandate in case of unsuccessful dismissal of the head of state by popular vote. At the same time, the new term of office begins for sustained President in such case (Čič, 2012; Drgonec, 2015).

In his comments on the constitutional position of the President, M. Čič (2012) also mentions other powers, which were adjusted by the 1999 amendment. Given the nature of this study, it is important to emphasize the strengthening of the Presidential veto for example. In the process of final approval of bills, the Constitution in its identical form stated (Art. 87 par. 4) that the President was obliged to return a bill to the Parliament for redebating it again in the Chamber also at the request of the Government, not only upon own autonomous decision (Čič, 1997). On the contrary, after the removal of this constitutional anomaly, the presidential veto was strengthened by changing the limit for approving the bill from a simple to an absolute majority of all members of the Parliament, i.e. at least by 76 MPs (Čič, 2012). Therefore, in this study attention is paid to the Presidents in Office after the 1999 constitutional change, as this opens thus an opportunity to compare the selected powers resulting from this constitutional adjustment. This office was gradually held by Rudolf Schuster, Ivan Gašparovič, Andrej Kiska, and currently Zuzana Čaputová. However, as the ambition is to compare the real influence the individual Presidents had on the exercise of their powers, the paper examines only the completed 5-year electoral cycles (1999-2004, 2004-2009, 2009-2014, and 2014-2019). The sources used for obtaining all the relevant information on individual acts within the exercise of the presidential powers was the official website of the President of the Slovak Republic (www.prezident.sk), with structure also including sections dedicated to the former Presidents. Significant shortcoming of this website in March 2021 was the fact, that data from Andrej Kiska's term of office were not stored separately - in the form of a closed chapter with summary data. 
Thus, the activities of current President Zuzana Čaputová are merged with the activities of her predecessor Andrej Kiska. It was therefore necessary to check the date of their implementation.

\section{AN OVERVIEW OF THE LITERATURE}

Issues of the relationship between the President and the exercise of his/ her constitutional powers have been in the centre of scientific research for many decades. This area directly relates to the study of a political system of any country. This is especially significant in the countries with a parliamentary form of government and an elected President - either directly by citizens or indirectly by parliament (Cabada, Štollová, 2014). In the scholarly literature from Western Europe, the issue of the President with a mandate direct from the citizens and his/her position is the subject of research of several experts. Traditional authors, M. Duverger (Duverger, 1980) and G. Sartori (Sartori, 2001), who started a long-standing dispute over the proper concept of the issue of the Presidential position within parliamentary system, were essential for this research. To the date, there is a variety of publications and studies addressing the issue of directly elected President and his/her impact on the constitutional and political system, especially from the countries of Western Europe (e.g. Linz, 1994; Cheibub, 2006; Elgie, Moestrup, 2008; Elgie 2011).

The issues of position, powers and exercise of the presidency in scholarly literature are basically oriented into two main streams. The first one is represented by the authors of constitutional law, which naturally pay more attention to the constitutional position of this highest constitutional institution. Thus, they pay more attention to the static aspect. They do not observe the dynamic level, i.e. president as a specific politician in a specific political situation. The second group of authors is represented predominantly by political scientists, who are more concerned with the issues of the elections of head of stat. Here, this division may be further differentiated in the sense that the interest in the matters around the Slovak President has been increased in Czech Republic, due to the changes in the election of the President of Czech Republic.

Probably the first monograph dealing with the position of the Slovak President after the establishing an independent republic in 1993 was the work by L. Orosz and K. Šimuničová (1998), which described the first five years of the Office in the history. It was a kind of retrospective view on the mandate of the first President Michal Kováč. However, already at the time 
of publication of this monograph, an extensive change in the constitutional position of the head of state was launched, and culminated in constitutional changes in 1999 and 2001 (Čič, 2012). In the field of legal sources, a publication of similar extent was not published since. Closest in content was the publication by A. Kura (2003), but it was basically an extensive commentary on the constitutional amendment, without considering any context from political science point of view. A rather accomplished piece of work is the monograph by M. Tóthová (2015) published at the University of Košice, but again it predominantly describes the position of head of state within its constitutional definition. Such study was also accomplished by Z. Koudelka (2018) in the Czech Republic, as he logically dealt with the issue of Czech realities, but used several parallels from the Slovak setting, and therefore, also this work needs to be considered here. An example of a study on matter of the President conducted by a constitutional lawyer exploiting a vocabulary of political science is the book by one of a former presidential candidate, R. Procházka (2019). The first and essentially more coherent publication about the role of the head of state from the view of political science was a scholarly study by P. Horváth (2000). In the Slovak area, several authors have dealt with the Presidential issues only in the form of research papers and chapters in books and journals. Again, from the area of constitutional lawyers, publications within the constitutional system could by mentioned, such as those by L'. Cibulka (2013) or J. Svák (2011). A more comprehensive elaboration about the head of state office are also in extensive commentaries on the Slovak constitution, both from the first President of the Constitutional Court, M. Čič (2012) and former constitutional judge J. Drgonec (2019). Other authors dealt with partial topics (within the scope of this study) in expert articles, especially in the periodicals as "Justičná revue" and "Právny obzor". Here, following authors are worth mentioning, as for example M. Domin (2013 and 2014), as well as J. Drgonec (2005 and 2013), K. Galdunová (2003), M. Káčer (2018), T. Lalík (2014), R. Maník (2004), J. Neumann (2017 and 2018), M. Nikodým (2012 and 2013) B. Šramel (2015a and 2015b) or Z. Zelenajová (2016). Monothematic issue of the journal Acta Universitatis Carolinae Iuridica from the Faculty of Law of Charles University should also be mentioned, as it was published at the time of the constitutional change in the election of the Czech President, where M. Giba (2011) together with P. Horváth and P. Juhás (2011) published interesting analytical experiences of direct election of head of state in Slovakia. Other Czech constitutional lawyers, e.g. J. Gric (2019), K. Klíma (2008), J. Reschová (2019) or P. Šutka (2016) had also analysed the exercise and scope of 
Presidential powers in their extensive publications, which are also relevant to the Slovak realities. In 2008, when an extensive expert discussion about the position and possible change of the form of government began, colleagues from Brno published a book entitled "The position of the president in the constitutional system of the Czech Republic" (orig. Postavenie prezidenta v ústavnom systéme Českej republiky), where several interesting studies were included significantly influencing the course of this discussion. The most interesting were the chapters by A. Gerloch (2008), V. Hloušek (2008), L. Kopeček (2008), Z. Koudelka (2008), J. Kysela (2008), M. Novák (2008), and J. Wintr (2008). Probably political scientists from Prague - M. Brunclík and M. Kubát (2017 and 2019) - achieved the greatest response from the worldwide political-science community due to their study on the Presidents in the Central European environment. From the point of view of Slovak and Czech political science, studies devoted to the direct electoral process of the head of state are also important, especially from M. Rybáŕ (2005 and 2010), who also published some of his researches with P. Spáč (2014 and 2015). So far, the last Presidential elections (2019) were analysed in more detail by three authors - L'. Zvada, M. Petlach and M. Ondruška (2020) for example. However, the issue of this paper, i.e. the comparison of the exercise of specific competencies of the Presidents of Slovak Republic since the introduction of direct election (1999 - 2019), has not been addressed in this form by any author so far.

\section{AN OVERVIEW OF THE EXERCISE OF THE SELECTED PRESIDENTIAL POWERS IN THE PERIOD OF 1999 - 2019}

When aimed to definition of the selected categories within which this examination of the exercise of Presidential powers is conducted, it is necessary to define basic constitutional framework of these competences first. D. Krošlák (2016) divides them into categories: a) relation to foreign countries (area of international agreements, diplomatic missions); b) relation to the legislature (laws, summoning and dissolution of parliament); c) relation to the government (appointment and dismissal); d) relation to the judiciary (appointment and dismissal of general and constitutional judges, the Attorney General and three members of the Judicial Council); e) creative powers (appointment and dismissal of state officials, appoints rectors and university professors, generals of the army); f) prerogatives of the head of state (pardoning and reducing of sentences, and awarding the state decorations); g) military powers (Commander in Chief of the Armed Forces). 
From our point of view, different categorizations are more appropriate, based on the real participation of the head of state when applying these categories. M. Tóthová (2015) simplified these Presidential powers and divided them into two basic categories: self-imposed, and bound. The selfimposed powers included those, which are implemented by the head of state autonomously. Powers, which are implemented in cooperation with other constitutional bodies, are hence defined as bound ones.

From the point of the comparison of selected Presidential powers in the years $1999-2009$, we have selected those, which are tied to the possibility of the President's direct influence. Thus, our research omitted those, in which the President presents just the role of ceremony, without greater power to change the decision of other bodies (Prime Minister, Government, Parliament, Judicial Council, etc.). The next sections of the papers, the text focuses on the following constitutional powers of the President:

a) The right of Presidential veto within the legislative process;

b) The granting of amnesty and pardons;

c) State of the Republic Speeches;

d) Foreign policy - acceptance of visits at home and visits abroad;

e) Power to award state decorations.

\section{Ad a) The right of Presidential Veto Within the Legislative Process}

The Constitution of the Slovak Republic grants a relative veto power to the head of state (Article 102, paragraph 1, letter o)). Given the fact that President does not have a right of legislative initiative, this is the only way he/she can influence the law-making process. By signing the law, the President expresses his/her approval of the content of the law. In case of doubt or disagreement, the President has the right to return the adopted law to the National Council of the Slovak Republic within 15 days, for redebating and removal of the questionable paragraphs. The relativity of this right lies in the fact that members of Parliament have an option to disregard the proposals of the head of state and re-introduce the identical bill by an absolute majority of all the MPs, i.e. by at least 76 votes out of 150 total MPs. In such a case, even if the President refused to sign such a law again, the law is considered approved (Drgonec, 2005; Neumann, 2005; Čič, 2012; Krošlák, 2016). Not only the factual, but also the political level is important within the use of the right to renegotiate laws. The exercise of this right, to a large extent, takes into account the criteria of political vicinity to the current parliamentary majority, which is especially evident with Rudolf Schuster. 
Although he was close to the governing coalition at the beginning of his term, he gradually became shifting away and more distant from it. Largely after he personally experienced temporary suspension of his Presidential powers during his hospitalization, while he was in induced sleep in Salzburg. This was accompanied with the decline of his home political party (SOP party) in preferences, combined with the creation of a new government in 2002, and the attempt to re-elect him in the 2004 elections. This caused his extremely critical relationship to several adopted laws. Although, in general, success of exercising Presidential veto is low, it remains an expression of a President's personal position to the matter in question, but also to the form how the laws are passed (Horváth, 2015). On the other hand, we can state that the Presidents (with the exception of Rudolf Schuster) did not abuse this right, even if they felt relatively far from a positive attitude towards the governing cabinet. Example of Andrej Kiska could be used in this context, as he was an opponent of the governing cabinet's opinions throughout his term of office. Certainly, the fact that the past coalitions did manage to gain the necessary majority to override a Presidential veto at the parliamentary level, also played a role.

Table 1: Vetoes of Bills by the Presidents of the Slovak Republic to be re-considered, as During Their Terms of Office

\begin{tabular}{|c|c|c|}
\hline \multicolumn{3}{|c|}{$\begin{array}{l}\text { Vetoes of Bills by the Presidents of the Slovak Republic to be re-considered, } \\
\text { as During Their Terms of Office }\end{array}$} \\
\hline President & Term of office & $\begin{array}{l}\text { The number of Bills } \\
\text { Vetoed }\end{array}$ \\
\hline Rudolf Schuster & $1999-2004$ & 103 \\
\hline Ivan Gašparovič & $2004-2009$ & 48 \\
\hline Ivan Gašparovič & $2009-2014$ & 51 \\
\hline Andrej Kiska & $2014-2019$ & 39 \\
\hline
\end{tabular}

Source: the authors, based on statistical overviews of the National Council of the Slovak Republic (www.nrsr.sk)

Table 2 is even clearer, expressing the percentage share of bills returned by the President for re-consideration to the Chamber, by individual years. It is apparent here, that the larger count of vetoes was in the years where Presidents had a personal dispute with the Prime Minister. During the years 2000 - 2004 it was Rudolf Schuster against Mikuláš Dzurinda - after the case 
of the Presidential surgery in Austria, in 2011 it was Ivan Gašparovič and the government during the resignation of Iveta Radičová, and finally Andrej Kiska at the end of the government of Robert Fico.

Table 2: Overview of the Number of Laws Passed in the National Council of the Slovak Republic and the Number of Bills Vetoed by the Presidents

\begin{tabular}{|c|c|c|c|}
\hline \multicolumn{4}{|c|}{$\begin{array}{c}\text { Overview of the Number of Laws Passed in the National Council of the } \\
\text { Slovak Republic and the Number of Bills Vetoed by the Presidents (in \%) }\end{array}$} \\
\hline Year & $\begin{array}{c}\text { Number of Laws } \\
\text { Passed }\end{array}$ & $\begin{array}{c}\text { Number of Bills } \\
\text { Vetoed by the } \\
\text { President }\end{array}$ & $\begin{array}{c}\text { Share of Bills } \\
\text { Returned (in \%) }\end{array}$ \\
\hline $\mathbf{1 9 9 9}$ & 95 & 1 & 1.0 \\
\hline $\mathbf{2 0 0 0}$ & 120 & 24 & 20.0 \\
\hline $\mathbf{2 0 0 1}$ & 118 & 25 & 21.2 \\
\hline $\mathbf{2 0 0 2}$ & 189 & 21 & 11.1 \\
\hline $\mathbf{2 0 0 3}$ & 175 & 25 & 14.3 \\
\hline $\mathbf{2 0 0 4}$ & 181 & 20 & 11.0 \\
\hline $\mathbf{2 0 0 5}$ & 143 & 11 & 7.7 \\
\hline $\mathbf{2 0 0 6}$ & 38 & 0 & 0 \\
\hline $\mathbf{2 0 0 7}$ & 143 & 8 & 5.6 \\
\hline $\mathbf{2 0 0 8}$ & 142 & 4 & 2.8 \\
\hline $\mathbf{2 0 0 9}$ & 147 & 9 & 6.1 \\
\hline $\mathbf{2 0 1 0}$ & 113 & 11 & 9.7 \\
\hline $\mathbf{2 0 1 1}$ & 138 & 23 & 16.7 \\
\hline $\mathbf{2 0 1 2}$ & 100 & 4 & 4.0 \\
\hline $\mathbf{2 0 1 3}$ & 137 & 10 & 73 \\
\hline $\mathbf{2 0 1 4}$ & 87 & 5 & 5.7 \\
\hline $\mathbf{2 0 1 5}$ & 148 & 11 & 7.4 \\
\hline $\mathbf{2 0 1 6}$ & 56 & 1 & 1.8 \\
\hline $\mathbf{2 0 1 7}$ & 107 & 12 & 11.2 \\
\hline $\mathbf{2 0 1 8}$ & 119 & 11 & 9.2 \\
\hline $\mathbf{2 0 1 9}$ & 165 & 11 & 6.7 \\
\hline
\end{tabular}

Source: the authors, based on their personal archives 


\section{Ad b) The Power to Grant Amnesty and Pardons}

Pardon and amnesty are legal institutes recognized in modern and democratic countries with rule of law applied. The main purpose and meaning of pardon and amnesty is the reduction or complete remission of sentences imposed by the competent courts. (Chovanec, Palúš, 2004). The legal institutes of pardon and amnesty are still relevant today, and in the conditions of Slovak Republic both of them are exclusive constitutional competence of the head of state. The President of the Slovak Republic is entitled to grant individual pardon to a specific person, as well as to issue a decision on granting an amnesty - in cooperation with the Prime Minister of the Slovak Republic, or with the Minister of Justice (Domin, 2015). Both legal institutes are primarily related to constitutional and criminal law, but at the same time, they have a direct impact on the lives of specific persons to whom the Presidential pardon has been granted, or the granted amnesty included them. Nevertheless, the terms "pardon" and "amnesty" cannot be interpreted as synonyms (Drgonec, 2012). Amnesty is the right of the President to decide on the removal of sentences for a certain group of convicts. Thus, it generally applies to a wider range of unspecified persons. On the other hand, granting the pardon is an individual decision of the entitled person - the President of the Slovak Republic in this case, against a specific individual. In other words, legal consequences of the granted pardon concern a specific individual, in accordance with the content and extent of the pardon. Pardon is usually granted at the request of a particular person. The decision to grant an amnesty is a collective decision and does not apply to a specific individual, but to all persons fulfilling the objective conditions defined in the decision about the amnesty granted. Another fundamental difference between pardon and amnesty is in the way they are granted. The decision to grant a pardon is an individual act of the President and is not published in the Collection of Laws (Drgonec, 2012). The decision to grant an amnesty is generally binding legal regulation, which is published in the Collection of Laws of the Slovak Republic. Therefore, granting an amnesty is usually accompanied by exceptional, society-wide events, e.g. on the anniversary of the establishment of Slovak Republic, or on the occasion of the Presidential election. The President's power to grant pardon and amnesty has undergone certain development, as this power has been gradually narrowed in comparison with its original entry in the newly adopted Constitution of the Slovak Republic. This minimalisation of the competences of the head of state in this field occured mainly due to the negatively perceived so-called 
Mečiar's amnesties, generally perceived as an improper interference with the law enforcement bodies in a particularly serious and nationally sensitive issue of the abduction of Michal Kováč Jr., the son of the former President of the Slovak Republic. The originally autonomous power of the President thus became the "bounded power" of the head of state, as the President can perform it only with the participation of other responsible authority - in this case with the participation of the Prime Minister, or other appointed minister (Orosz, Šimuničová, 1998). At the same time, it is impossible to grant pardon and amnesty in pending criminal proceedings. The granting an individual pardon is an exclusive power of the President and does not require any consent of another authority.

The Presidents of the independent Slovak Republic used their powers to grant a pardon or an amnesty to varying degree. From the above comparison of the number of pardons and amnesties granted, it is clear that President Rudolf Schuster used his competence in this area the most, granting a total of 73 individual pardons during his term as the President of the Slovak Republic. During his single term, he granted twice as many pardons as Presidents Ivan Gašparovič (during two terms) and Andrej Kiska (one term) together. Overall, President Andrej Kiska granted the least individual pardons and did not grant a single amnesty. Each of the previous Presidents granted one amnesty in each of their terms of office. The exception is President Rudolf Schuster again, who granted two amnesties. In addition to the decisions on granting amnesty issued by former Presidents, three more decisions on granting amnesty were issued in the era of independent Slovak Republic. There were two so-called Mečiar's amnesties granted by then Prime Minister Vladimír Mečiar, and a subsequent amnesty granted by the later Prime Minister Mikuláš Dzurinda, who wanted to repeal the previous socalled Mečiar's amnesties. These amnesties were granted during the periods when the Slovak Republic did not have an elected President and the prime ministers were temporarily in presidential powers. Paradoxically, these decisions on granting an amnesty had caused the biggest contradictions in the society with long-time effects. (Drgonec, Kvasničková, 2000).

Despite the fact that we are not dealing with the current President Mrs. Zuzana Čaputová in this study, the possible issue of granting an amnesty could be highly topical during the Covid 19 pandemic. General hygienic and epidemiological measures are aimed at minimizing mobility, avoiding gathering of large groups of people, as well as ensuring thorough quarantine of infectious persons positively diagnosed with COVID-19 virus. Especially, isolation of patients and people with diagnosed with COVID-19 virus is an 
important measure to eliminate further spread of the virus. It is clear that compliance with these principles is more complex and limited in correctional facilities providing a custodial sentence. According to the media coverage about the long-lasting full capacity of correctional institutions (Trend, 2018) it is clear, that ensuring thorough isolation of a convict who is Covid 19 positive is extremely challenging. One of the solutions that could possibly help is to free up the capacity of these institutions, thus granting an amnesty. Granting an amnesty could for example result in the remission of the rest of the sentences for a precisely defined group of convicts, which would create better conditions for ensuring quarantine in correctional institutions, allow the separate placement of Covid 19 positive convicts, etc. The amnesties granted so far were generally associated with special and ceremonial events, anniversaries, or national holidays. Thus, the granting of an amnesty due to a pandemic could be unique, but possibly also appropriate and practical in terms of improving the epidemiological situation in correctional facilities. In order to confirm this hypothesis, it would be necessary to carry out a thorough epidemiological analysis in the environment of correctional facilities providing a custodial sentence, as well as to know specific and accurate data about the impact of Covid 19 pandemic on the persons serving a custodial sentence. According to media releases, in a letter addressed to the President of the Slovak Republic, relatives of some convicts requested granting an amnesty for an unspecified group of convicts, expressing their concerns about the health and safety of their convicted relatives (RTVS, 2021). Compared to previous amnesties granted by the Presidents of the Slovak Republic in the past, this would be a significantly different reason for granting an amnesty, as the justification of granting an amnesty due to an unfavourable pandemic situation is unparalleled in the history of the Slovak Republic.

Table 3: Number of Amnesties and Pardons Granted by the Presidents of the Slovak Republic during Their Terms of Office

\begin{tabular}{|c|c|c|c|}
\hline \multicolumn{4}{|c|}{$\begin{array}{c}\text { Number of Amnesties and Pardons Granted by the Presidents of the Slovak } \\
\text { Republic During Their Terms of Office }\end{array}$} \\
\hline President & Term of Office & $\begin{array}{c}\text { Amnesties } \\
\text { Granted }\end{array}$ & Pardons Granted \\
\hline Rudolf Schuster & $1999-2004$ & 2 & 73 \\
\hline Ivan Gašparovič & $2004-2009$ & 1 & 12 \\
\hline
\end{tabular}




\begin{tabular}{|c|c|c|c|}
\hline Ivan Gašparovič & $2009-2014$ & 1 & 16 \\
\hline Andrej Kiska & $2014-2019$ & 0 & 6 \\
\hline
\end{tabular}

Source: the authors, according to statistical overviews available online at www. prezident.sk

\section{Ad c) State of the Republic Speeches}

Position of the President of the Slovak Republic, intended as the head of state, also includes the competence of delivering a speech on the state of the Slovak Republic and other topical political issues. The President delivers this speech in the chamber of the legislative body (Article 102, paragraph 1, letter p) of the Constitution of the Slovak Republic). It considered a traditional legal act, as in our territory its history is tracked back to the first Czechoslovak President T.G. Masaryk (Orosz, Šimuničová, 1998; Čič, 2012; Domin, 2014; Drgonec, 2015). Given the conception of executive power in Slovakia, where the President is primarily a connecting element for the proper functioning of constitutional institutions (Krošlák, 2016, Gric, 2019), this speech is delivered before members of the Parliament, but citizens are primarily the intended addressees. Especially when the head of state is elected in direct elections, such a speech should not be considered only as a description of the current state of country, but also as the President's message delivering own perception, thoughts about the current course of the society, and own visions on the country's eventual development in the future. Given the already mentioned nature of the political system, such a report does not obviously have a fundamental impact on political actors (Horváth, 2019). It is certainly an interesting fact that in the history of Slovak parliamentarism, the first such Presidential speech from 1994 was the one of the utmost importance for the further operation and existence of the cabinet, as the head of state called for a change in political conditions during this speech. The words of Michal Kováč delivered on the $9^{\text {th }}$ of March 1994 had directly resulted in a vote of no confidence for the second government of Vladimír Mečiar and the rise of the government of Jozef Moravčík (Kopeček, 2007). No other speech on the state of the Slovak Republic has had such a significant impact on the development of Slovak political scene. Even at the time of the political crisis in March 2018, which resulted in a change of prime minister due to the assassination of journalist Ján Kuciak and his fiance, no such report was presented then by President Andrej Kiska, even though he was expected doing so. It was presented in June 2018, after the appointment of the government of Peter Pelegrini. In the retrospective and hypothetical 
consideration, if this report was presented earlier, it would probably be the second report on the state of the Slovak Republic, which would result in a change at the post of Prime Minister. Presidents Rudolf Schuster and Andrej Kiska used this tool regularly, at annual intervals, except for their final year in office, which was probably due to fact they wished to continue their political carrier (Rudolf Schuster ran for President again in 2004 and Andrej Kiska established the political party "Za ludí", which he ran with in parliamentary elections in 2020). Only Ivan Gašparovič used this right to a much lesser extent, especially during his second term (Domin, 2014).

Table 4: Overview of the State of the Republic Speeches delivered by the Presidents of SR

\begin{tabular}{|c|c|c|c|}
\hline \multicolumn{5}{|c|}{ Overview of the State of the Republic Speeches delivered by the Presidents } \\
of SR
\end{tabular}

Source: the authors, based on www.prezident.sk

\section{Ad d) Foreign policy - acceptance of visits at home and visits abroad}

Within the framework of the constitutional powers of President of the Slovak Republic, the role of representation abroad appears the most accepted. Having analysed the data in Table 5, the logical result is mainly the knowledge of the political character and acceptance of the President of the Slovak Republic abroad. The number of receptions prepared as well as the number of visits by the heads of other states in Slovakia is not only the result of good relations of our Presidents internationally, but of the entire Slovak Republic. Again, we can say that with the exception of the period of Andrej Kiska in office, these statistics are very balanced. Although there is a significant decrease in official receptions in his case, it did not mean foreign isolation of the Slovak Republic. One possible explanation is the fact that the Slovak Republic was represented by the Prime Minister abroad more often 
(for example, the reception of Peter Pellegrini with the Presidents of Russia and the USA during the presidency of Andrej Kiska).

Table 5: Number of Accepted Visits of Foreign Heads of State, and Official Visits Abroad made by the Presidents of the Slovak Republic during Their Terms of Office

\begin{tabular}{|c|c|c|c|}
\hline \multicolumn{4}{|c|}{$\begin{array}{c}\text { Number of Accepted Visits of Foreign Heads of State, and Official Visits } \\
\text { Abroad made by the Presidents of the Slovak Republic during Their Terms } \\
\text { of Office }\end{array}$} \\
\hline President & Term of office & $\begin{array}{c}\text { Number of Visits } \\
\text { Accepted }\end{array}$ & Number of Visits \\
\hline Rudolf Schuster & $1999-2004$ & 38 & 36 \\
\hline Ivan Gašparovič & $2004-2009$ & 44 & 26 \\
\hline Ivan Gašparovič & $2009-2014$ & 50 & 29 \\
\hline Andrej Kiska & $2014-2019$ & 22 & 32 \\
\hline
\end{tabular}

Source: the authors, based on www.prezident.sk

\section{Ad e) Power to award state decorations}

From the aspect of exercising the Presidential powers, it is certainly worth of analysing the power of the head of state to award the highest state awards. On the one hand, this belongs significantly to the ceremonial powers - on the other hand, it indicates a lot about the mental setting of the President and, to a large extent, the degree of acceptability of the President on the domestic and foreign scene. The issue of state decorations is not regulated in any special way. It can be granted either on Presidents own initiative, or based on a proposal - especially from the government cabinet, but any citizen of the Slovak Republic can also submit a proposal (Drgonec, 2019). Act No. 522/2008 Coll. on state awards lists the basic types of these decorations. These are Order of the White Double Cross (WDC, awarded to citizens of other countries for the development of mutual relations with Slovakia); Order of Andrej Hlinka (AH, awarded to citizens of Slovakia for outstanding merits of the establishment of the Slovak Republic); Order of L'udovít Štúr (ĽŠ, awarded to citizens of the Slovak Republic for merits of the democracy development); The Cross of Milan Rastislav Štefánik (MRŠ, awarded to citizens of the Slovak Republic for risking their own lives in defence of the republic or saving lives and property); The Cross of 
Pribina (awarded to citizens of the Slovak Republic for economic, social or cultural development); and the Medal of the President of the Slovak Republic (awarded to citizens of the Slovak Republic for merits of the state administration or the development of the defence and security of the republic). Due to the fact that the Order of Andrej Hlinka for outstanding merits of the establishment of the Slovak Republic was primarily awarded in the first decades after the establishment of an independent republic, Table 6 below provides an overview of the decorations awarded continuously during the examined period.

Table 6: Number of State Decorations Awarded by the Presidents of the Slovak Republic During Their Terms of Office

\begin{tabular}{|c|c|c|c|c|c|}
\hline \multicolumn{6}{|c|}{ Number of State Decorations Awarded by the Presidents of the Slovak } \\
Republic During Their Terms of Office
\end{tabular}

Source: the authors, according to the website: www.prezident.sk

The most active President in the field of international relations was Rudolf Schuster, who awarded the highest awards to foreign nationals in 24 cases. This activity can be attributed both to his excellent language skills and to his previous position in diplomatic services of the former federal state. The second significant impulse was the substantial diplomatic activity of the President and government in completing the process of the country's integration into the European Union and NATO. On the contrary, Andrej Kiska was the most active President in awarding the most important state decorations to the citizens of the Slovak Republic, which may reflect his ambition to continue political carrier within his own political party after finishing his term. 


\section{THE POLITICAL DIMENSION OF THE PRESIDENCY}

Lastly, it is certainly interesting to analyse the factors, which do not shape the mandate of the President at the very beginning of his/her supreme constitutional office constitutionally, but politically. The first President Michal Kováč is especially appreciated because in the history of the Slovak Republic he was the only candidate for this position, who managed to gain the confidence of members of the Parliament by a constitutional majority, i.e. 106 out of 142 submitted votes (Orosz, Šimuničová, 1998; Kopeček, 2007). In the case of directly elected Presidents, it is interesting to see whether they were solid favourites during the whole electoral campaigning, whether they managed to gain majority votes cast in the first round, or whether their mandate was a result of re-grouping of the voters between the first and second round.

Table 7: Overview of Gains of the Presidents of the Slovak Republic in Direct Elections/by Rounds I and II

\begin{tabular}{|c|c|c|c|c|}
\hline \multicolumn{5}{|c|}{ Overview of Gains of the Presidents of the Slovak Republic in Direct } \\
Elections/by Round I and II
\end{tabular}

Source: the authors, based on the elections results available at: www.statistics.sk

The table above with an overview of the Presidential elections demonstrates that the first category (being a solid favourite) is formed by Rudolf Schuster and second electoral period of Ivan Gašparovič so far, with the electoral gains over $45 \%$ confirmed in the second round. These were the candidates with official support of the government coalitions (Rybár, Spáč, Voda, 2014; Rybář, Spáč, 2015). On the contrary, Ivan Gašparovič (first term of office) and Andrej Kiska stepped into the second rounds on second 
places (the winners from the first round were Vladimír Mečiar and Robert Fico). They managed to benefit from the public mood, as anyone appeared a better choice than the winners of the first round at the time (Kopeček, 2007; Horváth, Juhás, 2011, Rybář, Spáč, Voda, 2014; Rybář, Spáč, 2015). The current head of state, Zuzana Čaputová, won her seat by winning both electoral rounds, with her second- round electoral gain amounting to $58.4 \%$ $(1,056,582$ of votes cast). This result could be rated to the average results, considering the previous Presidents (Election of the President of the Slovak republic 2019, 2019). An interesting issue is the age of the candidates when taking their office, which is clearly moving towards a younger age. Unlike the US Presidents for example, in Slovakia there is a significant shift of candidates towards the official minimum age of 40 years. The first President Michal Kováč was 62 years old on the day of his inauguration and the first two directly elected Presidents were aged 65 and 63 (of course, Ivan Gašparovič was 5 years older in his second term of office). Thus, the last two Presidents, Andrej Kiska (51) and current President Zuzana Čaputová (45) especially, had brought a significant generational change. It will therefore be interesting to observe whether this trend would confirm, or there will be a shift again towards higher aged candidates again. The effect of a strong and often aggressive campaign largely favours younger candidates, who are prepared to manage these inconveniences of direct election with less stress (Horváth, 2019).

This study focused on the exercise of Presidential powers since 1999, i.e. since the year when when the fundamental change of the position of the head of state was adopted. Initially, when the Slovak Republic was established in 1993, the indirect election of the President was constituted. Unconventionally, this procedure was extremely rigid for the parliamentary form of government. Even in the case of re-election of the President, the gain of constitutional majority of three-fifths (at least 90 votes out of a possible 150) was necessary. On the other hand, Presidential powers corresponded to such setting of electoral procedure. Again, within the parliamentary form of government, the President had an unconventionally strong position in relation to the government. In addition to the obligatory powers to appoint the Prime Minister regardless of the result of the parliamentary elections (which did not even happen), President also had the power to reject the Prime Minister's proposal to appoint a member of the government. This element resembled the Presidential model. Michal Kováč had actively used this competence several times, thus intervening into the process of forming the government. Therefore, after the parliamentary elections and 
the fundamental political change in 1998, in addition to the change from indirect to direct election of the President, the framework of presidential powers was also addressed. The direct election of the President by citizens ensures that at the end of the election race, a candidate is always elected - in the second round at the latest with a simple majority of votes cast. As an alternative would be implementation of gradually decreasing electoral quorum, as it was the case in the Czech Republic or Hungary at the time (Horváth, 2015).

The introduction of direct election of the President in Slovakia has fundamentally changed the view on electoral procedures - not only from the perspective of general public, but by the political parties as well. Until then, appointing of the head of state depended purely on the concord of the political parties represented in the Parliament. Hence, the direct election significantly reduced their influence. In addition, the non-partisan candidates are allowed to run for the office. During the examined period, a room for political parties to influence result of Presidential elections proves to be rather limited. The first directly elected President, Rudolf Schuster, ran as a joint candidate for then parliamentary coalition. Not all other Presidents, with the exception of Ivan Gašparovič in his second term, used this support. The second Presidential election in 2004 had already brought a major surprise. The candidate of the governing coalition and a clear favourite in the pre-election polls, Eduard Kukan, suffered of a "certain winner" effect - as his voters did not come to the ballot boxes. The duel between the two close former political colleagues (mainly in 1994 - 1998), was generally perceived as a choice of "lesser evil". Thus, former Speaker of the Parliament, Ivan Gašparovič defeated former Prime Minister Vladimír Mečiar, in the end. In the consecutive elections, two strong candidates of then coalition and opposition had met, Ivan Gašparovič and Iveta Radičová. Despite the fact that Iveta Radičová lost these elections by more than 240,000 votes in the second round, the following parliamentary elections in 2010 brought her position of the Prime Minister (although her office did not last even the half of its term). With his election in 2014, the third President Andrej Kiska had definitively broken the rule of the need for previous political career. Lacking any political experience he was able to take advantage of the part of the public which was dissatisfied with then Prime Minister Robert Fico, reversed the order in the second round and filled a vacant position in the Presidential palace. The story of the current President Zuzana Čaputová is of a similar scenario, although she held the position of vice-President of a nonparliamentary political party before running for President. In addition to the 
already mentioned trend of decreasing the age of the elected Presidents in Slovakia, the gender aspect is also worth mentioning. When no woman could not be even considered a relevant candidate in indirect elections (perhaps with the exception of Brigita Schmognerová, presidential candidate from 1998 unsuccessful elections), direct elections have gradually erased this obstacle. The independent candidate Magda Vášáryová lost in the 1999 direct Presidential elections, Iveta Radičová was defeated in the last round of 2009 elections, and in 2019 finally, Zuzana Čaputová won the Presidential elections. Thus, a long-term trend of gradually growing representation of women among the highest political officials in Slovakia (meanwhile, Ivetta Macejková held the formally fourth highest constitutional post as the President of the Constitutional Court of the Slovak Republic).

While examining the directly elected Presidents of the Slovak Republic it turned out, that it is often more interesting to follow their position before the elections and the way they got into this office, than the exercise of Presidential powers itself. Even when looking at the numerical expressions of the exercise of their individual powers, it is clear that the Office of the head of state itself and the formalized procedures have a large influence on particular decisions. A crucial factor for exercising the individual powers is the relationship of the head of state and the current political representation, at the level of the government. This relationship is probably the most important factor in exercising the powers - within the legislative process for example. If it is evident that the governing coalition enjoys a comfortable parliamentary majority, the right of relative veto decreases considerably for example, when compared to the passed laws. Since the times of Michal Kováč, the President has often become the second centre of power within the executive, representing a possible alternative to the current government. This can be clearly seen both with Rudolf Schuster (especially after the second half of his term of office) and Andrej Kiska. The latter even tried to enter the competition of political parties after the end of his office and showed even his ambition to become prime minister (in the end, this intention did not work out for him and he left political life). Slovakia after 1993 did not have any politician who could affect the country's modern history in a positive way, and thus play a certain positive role model for the future so far, and this statement unfortunately applies to the post of President. Although each of them spoke about the need to unite the society in their inaugural speeches, they divided it even more in the end. 


\section{CONCLUSION}

As declared in the introduction, the goal of primary research was to monitor the exercise of Presidential powers in the Slovak Republic during the years 1999-2019 and to conclude, whether their exercise of the Office was influenced by the personalities of individual Presidents, or it was more likely a result of their constitutional powers - with the personality component being secluded. On the basis of partial outcomes of the study here (overview of legislative activity, granting pardon and amnesty, delivering speech on state of the Slovak Republic, activities within foreign policy, awarding of state decorations) it turns out, that the position of the President of the Slovak Republic is primarily determined by its constitutional definition. There are no such essential circumstances in the overall overview, which would confirm, that the personality of then Presidents had a significant influence on the exercise of this highest office. On the other hand, some partial data also indicate that the exercise of the office of the President is in direct relation to the previous preparation for this position, e.g. their awareness of constitutional and political conditions in the given period. Especially with Andrej Kiska, it is clear that he was not identified at all with this office as if he was not a full-time President. His lesser activities within legislative process and international relations proved this (especially the number of heads of states visiting Slovakia and the number and quality of his visits abroad). It is probably a result of the fact that his election was the result of a fundamental political division of Slovak society. Ultimately, the election of the current President - not so politically experienced Zuzana Čaputová took place in a much smaller political conflict, without fundamental division of Slovak society, which had a positive effect on her current term of two years.

Secondly, we focused on the question of whether the exercise of the Presidential office varied in the second term, when compared to the first one. In this context, it is necessary to emphasize that Ivan Gašparovič is the only such example so far. Therefore, the results are affected by having only one example of such case. The main finding of this study is that there were no significant changes between the individual election periods of Ivan Gašparovič, and apart from the appearances in the Parliament, he was even more active within the remaining powers under analysis. However, a more relevant conclusion on this issue would only be possible in the case of reelection of another President in the future. On the other hand, it can be assumed that the second term gives preconditions for a better exercise of the Presidential office - for example, the President does not need a certain 
transitional period to be acquainted with the real requirements of this office. The execution of the Office of the President can continue uninterrupted, as well as the activities of all President's closest associates (Head of the Office and individual departments, advisers, etc.), thus from the day of the repeated taking of the Presidential oath, the President can continuously exercise his mandate even more dynamically as after entering his first term.

\section{REFERENCES}

BARDOVIČ, J. (2017). Majoritarian Formula and the relationship of Majority and Minority - Slovak Experience. In: Public Economics and Administration 2017: Proceedings of the 12th International Scientific Conference. Ostrava: VŠB - Technical University of Ostrava, 2017. pp. 32-35.

BELKO, M. (2003). Moc výkonná. In: KOPEČEK, L. (ed.). Od Mečiara k Dzurindovi. Slovenská politika a politický systém v prvním desetiltetí samostatnosti. Brno: IIPS, 2003. pp. $49-65$.

BRUNCLÍK, M., KUBÁT, M. (2017). Kdo vládne v Česku? Poloprezidentský režim, př́má volba a pravidla hry. Praha: Barristal \& Principal Publishing, 2017. 143 pp.

BRUNCLÍK, M., KUBÁT, M. (2019). Semi-Presidentialism, Parliamentarism and Presidents. Presidential politics in central Europe. New York: Routledge, 2019. 170 pp. DOI: https://doi.org/10.4324/9781315166452.

CABADA, L., ŠTOLLOVÁ, S. et al. (2014). Proměny postavení prezidenta ve střední Evropě. Brno: Václav Klemm, 2014. 199 pp.

CIBULKA, L'. (2013). Prezident Slovenskej republiky. In: SVÁK, J., CIBUL'KA, J. Ústavné právo Slovenskej republiky. Osobitná čast'. Bratislava: EUROKÓDEX, 2013. pp. 429-464.

ČIČ, M. et al. (1997). Komentár k Ústave Slovenskej republiky. Martin: Matica slovenská, 1997. 598 pp.

ČIČ, M. et al. (2012). Komentár $k$ Ústave Slovenskej republiky. Žilina: Eurokódex, 2012. $827 \mathrm{pp}$.

DOMIN, M. (2013).Zodpovednot' za kontrasignované rozhodnutia prezidenta Slovenskej republiky. In: Justičná revue. Vol 65, No.4, 2013. pp. 443-463.

DOMIN, M. (2014). Správa o stave republiky ako prezidentská právomoc. In: Justičná revue. Vol 66, No.8-9, 2014. pp. 1049-1066

DOMIN, M. (2015). Inštitút kontrasignácie aktov hlavy štátu. Osobitne v podmienkach ústavného systému Slovenskej republiky. Bratislava: Studia Iuridica Bratislavensia, UK, 2015. 148 pp. 
DRGONEC, J., KVASNIČKOVÁ J. (2000). Mutácie ústavnosti. Bratislava: IVO, $2000.76 \mathrm{pp}$.

DRGONEC, J. (2005). Právo prezidenta Slovenskej republiky vrátit’ Národnej rade Slovenskej republiky zákon s pripomienkami. In: Justičná revue. Vol. 60, No.1, 2005. pp. 22-35.

DRGONEC, J. (2013). Obžaloba na prezidenta vo svetle prvej skúsenosti. In: Justičná revue. Vol. 65, No. 6-7, 2013. pp. 908-924.

DRGONEC, J. (2019). Ústava Slovenskej republiky. 2.vydanie. Bratislava: C.H.Beck, 2019. 1792 pp.

DUVERGER, M. (1980). A New Political System Model: SemiPresidential Government. In: European Journal of Political Research. Vol. 8, No. 2, 1980. pp. 165-187. DOI: https://doi.org/10.1111/j.1475-6765.1980. tb00569.x.

ELGIE, R. (2011). Semi-Presidentialism: Sub-Types and Democratic Performance. Oxford: Oxford University Press, 2011. 205 pp. DOI: https:// doi.org/10.1057/9780230306424.

ELGIE, R., MOESTRUP, S. (eds.) (2008). Semi-Presidentialism in Central and Eastern Europe. Manchester: Manchester University Press, 2008. 296 pp. DOI: https://doi.org/10.4324/9780203954294.

GALDUNOVÁ, K. (2003). Imunita a hlava štátu. In: Právny obzor. Vol. 86, No. 5, 2003. pp. 456-469.

GERLOCH, A. (2008). K problematice postavení prezidenta republiky v ústavním systému České republiky de constitutione lata a de constitutione ferenda. In: ŠIMÍČEK, V. (ed.). Postavení prezidenta v ústavním systému České republiky. Brno: MU - MPÚ, 2008. pp. 35-41.

GIBA, M. (2011). Vplyv priamej vol'by na ústavné postavenie prezidenta republiky na Slovensku. In: Acta Universitatis Carolinae Iuridica. Vol. 57, No. 4, 2011, pp. 101-114.

GRIC, J. (2019). Moc výkonná. In: RESCHOVÁ, J., KINDLOVÁ, M., GRINC, J., PREUSS, O., ANTOŠ, M. Státověda: Stát. Jednotlivec. Konstitucionalismus. Praha: Wolters Kluwer ČR, 2019. pp. 335-354.

HLOUŠEK, V. (2008). Přímá volba prezidenta - český kontext. In: ŠIMÍČEK, V. (ed.). Postavení prezidenta v ústavním systému České republiky. Brno: MU - MPÚ, 2008. pp. 263-285.

HORVÁTH, P. (2000). Funkcia prezidenta v ústavných systémoch. Bratislava: IVO, 2000. $77 \mathrm{pp}$.

HORVÁTH, P., JUHÁS, P. (2011). Zavádzanie priamej vol'by prezidenta na Slovensku a jej dôsledky. In: Acta Universitatis Carolinae Iuridica. Vol. 57, No. 4, 2011. pp. 115-128. 
HORVÁTH, P. (2015). Prezident v systéme výkonnej moci na Slovensku. Trnava: Spoločnost' pre verejnú správu pri SAV, 2015. 106 pp.

HORVÁTH, P. (2019). Aktéri verejnej politiky. Slovensko 2012 - 2016. Bratislava: IRIS, 2019. $106 \mathrm{pp}$.

CHEIBUB, J. A. (2006). Presidentialism, Parliamentarism and Democracy. New York: Cambridge University Press, 2006. 222 pp. DOI: https://doi. org/10.1017/CBO9780511813344.

CHOVANEC, J., PALÚŠ, I. (2004). Lexikón ústavného práva. Bratislava: Procom, 2004. $261 \mathrm{pp}$.

KÁČER, M. (2018). Ústavné zvyklosti a moc prezidenta v SR. In: Právny obzor. Vol. 101, No. 6, 2018. pp. 554-565.

KLÍMA, K. (2008). Prezident České republiky v komparativním pohledu (několik vybraných pohledů. In: ŠIMÍČEK, V. (ed.). Postavení prezidenta v ústavním systému České republiky. Brno: MU - MPÚ, 2008. pp. 16-23.

KOPEČEK, L. (2007). Politické strany na Slovensku. 1989 - 2006. Brno: CDK, 2007. $627 \mathrm{pp}$.

KOPEČEK, L. (2008). Prezident $v$ politickém systému Slovenska. In: NOVÁK, M., BRUNCLÍK, M. (eds.). Postavení hlavy státu v parlamentních a poloprezidentských režimech: Česká republika $v$ komparativní perspektivě. Praha: Dokořán, 2008. pp. 171-210.

KOUDELKA, Z. (2008). Vztah prezidenta a vlády v oblasti jmenování. In: ŠIMÍČEK, V. (ed.). Postavení prezidenta v ústavním systému České republiky. Brno: MU - MPÚ, 2008. pp. 169-178.

KOUDELKA, Z. (2018). Prezident republiky. Praha: Leges, 2018. 376 pp.

KROŠLÁK, D. (2016). Prezident Slovenskej republiky. In: KROŠLÁK, D. a kol. Ústavné právo. Bratislava: Wolters Kluwer, 2016. pp. 512-535.

KUBÁT, M. (2013). Současná česká politika. Co s neefektivním režimem ? Brno: Barristal \& Principal Publishing, 2013. 191 pp.

KURA, A. (2003). Prezident v systéme štátnych orgánov Slovenskej republiky. Komárno: KT, 2003. 90 pp.

KYSELA, J. (2008). Přímá volba prezidenta republiky jako symptom krize ligitimity ústavního systému ?. In: ŠIMÍČEK, V. (ed.). Postavení prezidenta $v$ ústavním systému České republiky. Brno: MU - MPÚ, 2008. pp. 42-59.

LINZ, J. (1994). Presidential or Parliamentary Democracy: Does It Make a Difference? In: LINZ, J., VALENZUELA, A. (eds.) The Failure of Presidential Democracy. Comparative Perspectives. Baltimore: John Hopkins University Press, 1994. pp. 3-87.

L'ALÍK, T. (2014). Právomoc prezidenta odvolávat' predsedu a podpredsedu ústavného súdu. In: Justičná revue. Vol. 66, No. 8-9, 2014. pp. 1067-1087. 
MANÍK, R. (2004). Zodpovednost' a zánik funkcie prezidenta Slovenskej republiky. In: Justičná revue. Vol. 56, No. 8-9, 2004. pp. 874-887.

MANÍK, R. (2005). K problematike podpisovania a vetovania zákonov hlavou štátu. In: Justičná revue. Vol. 57, No. 4, 2005. pp. 487-466.

NEUMANN, J. (2017). Postavenie prezidenta v ústavnom systéme Slovenskej republiky vo fáze hladania. In: Justičná revue. Vol. 69, No. 12, 2017. pp. 1514-1529.

NEUMANN, J. (2018). Zopár slov ku kreačným právomociam prezidenta SR. In: Právny obzor. Vol. 101, No. 5, 2018. pp. 508-519.

NIKODÝM. M. (2012). Ústavnoprávne postavenie prezidenta $v$ Ústave Slovenskej republiky In: Právny obzor. Vol. 95, No. 5, 2012. pp. 418-431. NIKODÝM. M. (2013). Pôsobnost' prezidenta v parlamentnej forme vlády. In: Právny obzor. Vol. 96, No. 6, 2013. pp. 582-596.

NOVÁK, M. (2008). Prezident, premiér a snahy o posílení výkonné moci. In: ŠIMÍČEK, V. (ed.). Postavení prezidenta $v$ ústavním systému České republiky. Brno: MU - MPÚ, 2008. pp. 9-15.

OROSZ, L., ŠIMUNIČOVÁ, K. (1998). Prezident v ústavnom systéme Slovenskej republiky. Bratislava: VEDA, 1998. $140 \mathrm{pp}$.

PROCHÁZKA, R. (2019). Král' otec. Od Kováča po Kisku alebo načo nám je prezident. Bratislava: N press, 2019. $192 \mathrm{pp}$.

RESCHOVÁ, J. (2019). Princip dělby moci. Horizontální struktura moci. In: RESCHOVÁ, J., KINDLOVÁ, M., GRINC, J., PREUSS, O., ANTOŠ, M. Státověda: Stát. Jednotlivec. Konstitucionalismus. Praha: Wolters Kluwer ČR, 2019. pp. 259-285.

RYBÁŘ, M. (2005). The Presidential election in Slovakia, April 2004. In: Electoral Studies. Vol. 24, No. 2, 2005, pp. 333-338. DOI: https://doi. org/10.1016/j.electstud.2004.10.007.

RYBÁ $̌$, M. (2010). The 2009 Presidential election in Slovakia. In: Electoral Studies. Vol. 29, No. 1, 2010. pp. 171-173. DOI: https://doi.org/10.1016/j. electstud.2009.09.001.

RYBÁŘ, M., SPÁČ, P., VODA, P. (2014). Prezidentské vol'by na Slovensku v roku 2014. Brno. CDK, 2014. 225 pp.

RYBÁ̌̌, M., SPÁČ, P. (2015). The March 2014 Presidential elections in Slovakia: the victory of a political novice. In: Electoral Studies. Vol. 38, 2015. pp. 88-90. DOI: https://doi.org/10.1016/j.electstud.2014.10.003. SARTORI, G. (2001). Srovnávací ústavní inženýrství. Zkoumání struktur, podnětú a výsledků. Praha: SLON, 2001. 238 pp.

SVÁK, J. (2011). Hlava štátu. In: OROSZ, L., SVÁK, J., BALOG, B. Základy teórie konštitucionalizmu. Bratislava: EUROKÓDEX, 2011. pp. 340-353. 
ŠTOLLOVÁ, S. (2014). Slovensko - od nepřímé k prímé volbě prezidenta. In: CABADA, L., ŠTOLLOVÁ, S a kol.: Proměny postavení prezidenta ve střední Evropě. Brno: Václav Klemm, 2014. pp. 35-55.

ŠRAMEL, B. (2015a). Zodpovednost' prezidenta SR v slovenskom právnom poriadku (1.). In: Justičná revue. Vol. 67, No. 1, 2015. pp. 1-16.

ŠRAMEL, B. (2015b). Zodpovednost' prezidenta SR v slovenskom právnom poriadku (2.). In: Justičná revue. Vol. 67, No. 2, 2015. pp. 137-155.

ŠUTKA, P. (2016). Zákon o volbě prezidenta republiky - prednosti a nedostatky ve srovnání s úpravami států Evropské unie. Praha: Leges, 2016. 272 pp.

TÓTHOVÁ, M. (2015). Hlava štátu v systéme del'by moci. Košice: UPJŠ, 2015. $186 \mathrm{pp}$.

WINTR, J. (2008). Prezident republiky jako reprezentant státu, garant řádu a moderátor politických sporů. In: ŠIMÍČEK, V. (ed.). Postavení prezidenta v ústavním systému České republiky. Brno: MU - MPÚ, 2008. pp. 24-34.

ZELENAJOVÁ, Z. (2016). „Prezidentská vláda“ alebo aké sú možnosti jej vytvorenia podla Ústavy SR. In: Justičná revue. Vol. 68, No. 10, 2016. pp. 1067-1074.

ZVADA, L., PETLACH, M., ONDRUŠKA, M. (2020). Where were the voters? A spatial analysis of the 2019 Slovak Presidential election. In: SlovakJournal of Political Sciences. Vol. 20, No. 2, 2020, pp. 176-205. DOI: https://doi. org/10.34135/sjps.200201.

ELECTION OF THE PRESIDENT OF THE SLOVAK REPUBLIC 2019. (2019). [online]. Available at: https:// https://volby.statistics.sk/prez/ prez2019/en/index.html. [Accessed March 10, 2021].

THE SLOVAK CONSTITUTION. (2021). [online]. Available at: https://www. ustavnysud.sk/ustava-slovenskej-republiky. [Accessed March 10, 2021]. 